\title{
Paideusis
}

\section{Teaching for Commitment: Liberal Education, Indoctrination, and Christian Nurture (Elmer John Thiessen)}

\section{Paul Beaudette}

Volume 10, Number 1, 1996

URI: https://id.erudit.org/iderudit/1073210ar

DOI: https://doi.org/10.7202/1073210ar

See table of contents

Publisher(s)

Canadian Philosophy of Education Society

ISSN

0838-4517 (print)

1916-0348 (digital)

Explore this journal

Cite this review

Beaudette, P. (1996). Review of [Teaching for Commitment: Liberal Education, Indoctrination, and Christian Nurture (Elmer John Thiessen)]. Paideusis, 10(1), 43-45. https://doi.org/10.7202/1073210ar viewed online.

https://apropos.erudit.org/en/users/policy-on-use/ 


\title{
Book Reviews
}

\author{
Elmer John Thiessen. Teaching for Commitment: Liberal Education, \\ Indoctrination, and Christian Nurture. Montreal \& Kingston: \\ McGill-Queen's University Press, 1993.
}

The thesis of this book is that initiation into the Christian tradition-most particularly in the context of religious instruction-should not automatically be labelled "indoctrination" in the negative sense in which that word has come to be generally understood. Indeed, the charge of indoctrination has been taken so seriously, says Thiessen, that many Christian educators have watered down the confessional dimension of their teaching to the extent that it fails in one of its primary functions-initiating people into the Christian tradition. What the book aims to do is to reformulate the ideal of liberal education and redefine the concept of indoctrination. The hope is that a thorough re-examination of the charge of indoctrination will assist in developing a constructive approach to religious education. The reworked ideal of liberal education and concept of indoctrination are applied to a state-maintained system of public education.

Thiessen's lengthy look at the notion of indoctrination focuses, in turn, on four different strands commonly thought to be essential to the concept: content, methods, intention, and consequences. He devotes a chapter to each of these interrelated facets of indoctrination, contextualizing his examination within the perspective of contemporary ideas about liberal education.

The ideal of liberal education, says Thiessen, is not just a single ideal, but a variety of differing conceptions, all of which are built on two central notions: a - more ancient, classical oratorical conception, characterized by a "dogmatist epistemology," "a belief that truth can be known and expressed," and a more recent Enlightenment, "liberal-free" conception characterized by such values as freedom, autonomy, individualism, equality, a suspicion of authority and tradition, toleration, critical rationality, science, and belief in progress-values that are central to defining the modern world or modernity. It is out of the context of this second ideal of liberal education, which adopts the anti-religious bias of the Enlightenment, that religious education has come under increasing suspicion, and the concem about indoctrination more prevalent.

Although he sees some difficulties with this ascendant ideal of liberal education, Thiessen does not want to reject it, but "to revitalize the ideal of liberal education, building on the strengths of liberalism, drawing on the correctives of conservatism, and thereby developing a more adequate notion of liberal education" (p. 54)-one out of which the reply to the charge of religious indoctrination will be made.

Thus, each essential criterion of indoctrination is related to a key ingredient of the ideal of liberal education: content to the scientific ideal, methods to the idea of rationality, intention to the ideal of autonomy, and consequences to the ideal of critical openness.

With regard to content, Thiessen shows how the common assumption that religion and science can be distinguished in terms of possessing or not possessing "doctrines" is problematic; in fact, they are much more alike than not alike in this respect. In terms of methods, it is demonstrated that non-rational methods of teaching (for example, initiating individuals into the forms of 
knowledge) are as characteristic of liberal education as they are of religious instruction. From the intentions perspective, which would characterize religion as stifling growth towards individual freedom, Thiessen wants to embrace a more realistic sense of self-definition than the strong liberal version of autonomy which dominates contemporary educational thought, but which he finds philosophically suspect. Comparing consequences and critical openness, finally, Thiessen sees a vagueness inherent in the notion of critical openness which lends itself to stretching the ideal to extremes-to defining it too idealistically.

Thiessen adds a fifth criterion to the concept of indoctrination: the institutional criterion. He calls attention to the fact that the charge of indoctrination is most often made against institutions. Once again, he demonstrates how the supposed "totality" of religious schools is equally characteristic of public schools.

The remainder of the book attempts to draw some conclusions as to how to reply to the charge of indoctrination as it is specifically applied to Christian nurture. Since, he says, the concept of indoctrination is itself unclear, it is hard to be clear about the concept of religious indoctrination. As he states in his introduction, however, since indoctrination in its pejorative sense can only be understood within the context of liberal education, then a reconstruction of the concept of indoctrination is dependent on a reconstruction of the ideal of liberal education. In this regard, he suggests some improvements to its metaphysics (a movement away from dogmatic empiricism), its theory of human nature (recognition that spirituality and communality are constitutive aspects of our humanity), epistemology (admitting the creative tension between authority and autonomy), and values (a normal as opposed to an ideal view of what it means to be a human being).

The final chapter shows how the reconstruction of the notions of liberal education and indoctrination works itself out in practice, especially with regard to Christian nurture. Thiessen provides us with five practical principles that should govern the initiation phase of Christian nurture, followed by eight which concern themselves more with the liberating phase associated with growth towards rational autonomy. His concluding suggestion, on a broader scale, is that the best guarantee against institutional indoctrination is that there be a plurality of institutions.

This is a timely remark. Recently, 65,000 Quebecers signed petitions insisting that parents have the right to decide whether their children go to confessional, non-confessional or secular schools, and the Ontario Separate School Trustees' Association presented to the Minister of Education on 10 October, 1996 a 26-page discussion paper which insists that distinct "educational communities" should be recognized in Ontario with their own "variations in instructional philosophy, language, and religion." On 21 November 1996, the Supreme Court of Canada ruled against a movement promoted by a coalition of Christian and Jewish leaders to win taxpayer funding for religious schools.

I found it difficult to take issue with much of what was expressed in this book. Thiessen is a clear writer who in each section seems to follow that old methodological adage: Tell them what you are going to say, say it, and then tell them what you have said. He avoids the use of highly technical terminology and, in this sense, his book is widely accessible to the range of public for which 
it would be of interest. His discussion of the issues involved seemed balanced enough to be acceptable to both of the (by no means similar) Christian denominational strands-Roman Catholicism and Evangelicalism—which Thiessen says bear the brunt of charges of indoctrination.

My own anguments were rather with liberal educational ideology Thiessen criticizes. To some of the authors he critically discusses, like Barrow and Woods, Hirst, Holley, Peshkin, and especially White, Callan, and Gardner, I want to reiterate Paolo Freire's key insight that to profess neutrality in areas of social concern is to tip one's hand as a supporter of the status quo. In this case, religious or denominational noninvolvement displays an allegiance to secular humanism, the prevailing cultural ideology. To use a parallel example, do any parents or teachers forswear a linguistic tradition for their children or students in order to protect their grammatical autonomy?

Without exception, however, every question and critique that occurred to me were voiced by Thiessen in the course of his book in a clear and forceful, yet respectful manner. He writes convincingly from a breadth of knowledge, an engaging rationality, a critical open-mindedness, and an abiding commitment.

Paul Beaudette, Religious Studies, Mount Saint Vincent University

\section{Jane Roland Martin, Changing the Educational Landscape: Philosophy, Women, and Curriculum. NY: Routledge, 1994.}

Changing the Educational Landscape is a synopsis of Jane Roland - Martin's philosophical enterprise between 1969 and 1993. The articles are loosely organized around the themes identified in the secondary title-philosophy, women, and curriculum. ${ }^{1}$ In Part One, Martin examines the implications of introducing women into the canon of educational thought; in Part Two, she supposes a newly cut curriculum based on lessons we can learn from problematizing obstacles in women's education. Except for the opening essay and the article "A Professorship and Office of One's Own" in Part One, all articles have been previously published.

The two main sections of her book are preceded by a somewhat autobiographical essay on her academic career which, in her words, moved "To Philosophy and Back Again" as her research questions and methods began to incorporate the significance of women in educational thought. The nonchronological arrangement of her articles does not readily illustrate this philosophical movement. However, a comparison between The Schoolhome: Rethinking Schools for Changing Families (Cambridge, MA: Harvard University Press, 1992) and an earlier work Explaining, Understanding, and Teaching (New York: McGraw-Hill, 1970) does reveal some changes in her philosophical enterprise and methods. Like most introductions, Martin's introductory essay walks the reader through the development of her ideas. Of particular interest is her personal account of her struggle to identify with the subject matter of philosophical inquiry. She explains that, as a young analytic philosopher, she felt alienated from her philosophical projects and from the realities of daily experience in schools. Among academics whose research (ideally) incorporates abstract concepts and objective analysis, this is a familiar, if not common, problem. A solution typified here in Martin's work is to set aside cause-effect 